J. Egypt. Soc. Parasitol. (JESP), 51(2), 2021: 289 - 296

(Online: 2090-2549)

\title{
PARASITIC CONTAMINATION OF TWO COMMONLY CONSUMED LEAFY VEGETABLES IN EL-KHARGA OASIS, UPPER EGYPT, AND EVALUATION OF HYGIENE PRACTICES AMONG THE VENDORS
}

\author{
By \\ SARA S. ABDEL-HAKEEM ${ }^{1}$, MERVAT M. KHALIFA ${ }^{2 *}$ \\ AND WAFAA A. MOHAMMAD ${ }^{3}$
}

Department of Zoology ${ }^{1}$, Parasitology Lab., Faculty of Science, and Department of Medical Parasitology ${ }^{2}$, Faculty of Medicine, Assiut University ${ }^{182}$, Assiut, and Department of Zoology ${ }^{3}$, Faculty of Science, New Valley University, Egypt

( ${ }^{\star}$ Correspondence: mervat@aun.edu.eg)

\section{Abstract}

Foodborne parasitic diseases cause human morbidity and mortality especially in the low- \& middle-income countries. This study identified the parasitic contaminated Eruca sativa \& Raphanus sativus cultivated in El-Kharga Oasis, Upper Egypt, as to seasonal variation and the vendors hygiene practices. A total of 270 samples of the two vegetables were purchased from public markets. Parasitic contamination was evaluated by sedimentation and flotation techniques with modified Ziehl-Neelsen stain. The results showed that 219(81\%) samples were contaminated with 13 different parasites. Ascaris lumbricoides $123(25.5 \%)$ and Cryptosporidium parvum (14.9\%) were the commonest ones and the highest contamination rate was in autumn (87\%) for E. sativa and in winter (87\%) for R. sativus. The contamination level was significant with the gender and washing practices of vendors. The current data gave evidence of the seasonal dynamics of acquiring parasitic infection due to consumption of raw vegetables, interaction, and its relevance with vendor's hygiene.

Keywords: El-Kharga Oasis, Food-borne parasites, Vendors, Health hygiene.

\section{Introduction}

Vegetables are an important source of dietary fiber, vitamins and minerals, have low energy density and provide a range of nutrients' required to regulate body's metabolic functions (Slavin and Lloyd, 2012). Thus, many people regularly consume fresh vegetables, which were sources of parasitosis associated contaminated fresh for sale vegetables (Hassan et al, 2012). But, apart from Egypt, disease outbreaks caused by the ingestion of contaminated vegetables and fruits pose a significant problem to human health in Saudi Arabia (Al-Megrin, 2010), in United States (Herman et al, 2015) in Turkey (Yeni et al, 2016), South Africa (Iwu and Okoh, 2019), UAR (El Bakri et al, 2020) and China (Li et al, 2020).

Generally, diarrhea (WHO, 2003), or food poisoning (Al-Agroudi et al, 2016) caused by raw vegetables or fruits consumption due to parasites, bacteria, or virus or residual insecticides (El-Bahnasawy et al, 2014), or irrigated with wastewater of man and animals (Al- Shawa and Mwafy, 2007), and/or farms (Daryani et al, 2008).

Generally, Eruca sativa oil and Raphanus sativus oil improve the glucose tolerance, $\&$ serum insulin level (Ahmed et al, 2016), but being risky when contaminated with parasites or microorganisms, insecticidal residue, bad transportation, industrial developm ent (Slifko et al, 2000), and/or marketing (Okyay et al, 2004).

The present study aimed to evaluate the parasitic prevalence and seasonal availability in two common leafy vegetables Eruca sativa (rocket) and Raphanus sativus (radish) in El-Kharga Oasis, Upper Egypt.

\section{Methods and Materials}

Descriptive study (cross-sectional) was conducted in the New Valley Governorate in El-Kharga Oasis in Upper Egypt, located between $22^{\circ} 30^{\prime} 14^{\prime \prime} \& 26^{\circ} 00^{\prime} 00^{\prime \prime} \mathrm{N}$ and between $30^{\circ} 27^{\prime} 00^{\prime \prime} \& 30^{\circ} 47^{\prime} 00^{\prime \prime} \mathrm{E}$, from November 2018 to October 2019.

Ethical approval: All participants were voluntary and informed the work and that the results would be confidential. Sheet and written consent were obtained. Ethical appr- 
oval was obtained from the Ethical Committee, Faculty of Medicine, Assuit University.

Data collection: A semi-structured questionnnaire was used to collect the information on parasitic risks contaminated with consumption of raw vegetables. A total of 54 vendors participated and the data were anonymous. The questionnaires were prepared in English and translated into Arabic language during the face to face interview. Questionnaire sheet included the sex, age and educational level, as well as knowledge about foodborne diseases and other factors that may be relevant for contamination as washing vegetables before display or not, freshly collected or preserved for more than 1 day, source of water used for washing. A total of 270 specimens were collected from different sales outlets. Vegetables (180 E. sativa \& 90 R. sativus) were collected with the roots placed in separate labeled clean polyethylene bags without any manual contact and immediately transported for processing and examinations.

Parasites were eight protozoa and five helminthes stages. Parasitological examination was done (Takayanagui et al, 2007) with mild modification. The vegetables were washed by putting in tank filled with dechlorinated water for 3-4min to remove mud. Approximately $200 \mathrm{~g}$ of each vegetable was soaked in a sterile glass container with $150 \mathrm{ml}$ of washing solution of phosphate-buffered saline ( $\mathrm{pH} 7.4$ ) and $0.01 \%$ Tween 80 (Sigma Aldrich, CAS no: 9005656) followed by vigorous shaking for $15 \mathrm{~min}$. The solution was then filtered through four-fold gauze, and dispensed into clean centrifuge tubes, and centrifuged at $2000 \times \mathrm{g}$ for $30 \mathrm{~min}$. Supernatant was decanted into another tube and examined by zinc sulfate flotation met- hod for cysts (El- Khabaz et al, 2019). Sediment pellet was mixed, and a simple smear was stained with iodine stain and microscopically examined for eggs, cysts, and larvae. Each sample was independently examined by low and high power magnifications as: a- a direct smear, in which a drop of sediment was applied on a clean slide and covered with a clean cover slip, b- an iodine smear, in which $0.1 \mathrm{ml}$ of sediment was mixed with a drop of Lugol's iodine on a clean slide, and c- sediment was stained with modified ZiehlNeelsen stain for Cryptosporidium oocysts (El-Naggar et al, 2006).

Statistical analysis: Data were analyzed by using SPSS software version 20 (IBM, Chicago, IL, USA), and summarized by descriptive statistics for infected parasites number and percentage (Mahmoud et al, 2020). Pearson's chi-squared test analyzed the prevalence of the examined vegetables during different seasons with total parasitic contamination and to correlate between socio-demographic and hygiene practices and vegetables contamination. $P$ values $\leq 0.05$ were considered significant. Ward's hierarchical cluster analysis was performed using PAST software to unify the groups so that the variation in these groups did not increase too drastically.

\section{Results}

The samples showed a high level of parasitic contamination in both the leafy vegetables with an overall prevalent rate of $219 / 270(81 \%)$. E. sativa showed a higher parasitic contamination level $(85 \%)$ than $R$ sativus (73\%). Contaminated vegetables $22 \%, 12 \%$ \& $47 \%$ showed single protozoan, single helminth, and mixed infections, respectively (Tab. 1), with mixed infection was significantly higher than a single infection either with protozoan or helminth $(P \leq 0.05)$.

Table 1: Prevalence of intestinal parasitic infections in examined fresh leafy vegetables.

\begin{tabular}{|c|c|c|c|c|c|c|c|}
\hline Vegetables & No & $+\mathrm{ve}$ & $\begin{array}{c}\text { One protozoan } \\
\text { No }(\%)\end{array}$ & $\begin{array}{c}\text { One helminth } \\
\text { No }(\%)\end{array}$ & $\begin{array}{c}\text { Mixed Infection } \\
\text { No }(\%)\end{array}$ & $\begin{array}{c}\text { Total protozoa } \\
\text { No }(\%)\end{array}$ & $\begin{array}{c}\text { Total helminths } \\
\text { No }(\%)\end{array}$ \\
\hline Eruca sativa & 180 & $153(85)$ & $42(23.3)$ & $21(11.7)$ & $90(33.3)$ & $132(73.3)$ & $111(61.7)$ \\
\hline Raphanus sativus & 90 & $66(73.3)$ & $18(20)$ & $12(13.3)$ & $36(40)$ & $54(60)$ & $48(53.3)$ \\
\hline Total & 270 & $219(81.1)$ & $60(22.2)$ & $33(12.2)$ & $126(46.7)$ & $186(68.9)$ & $159(58.9)$ \\
\hline
\end{tabular}

The frequency distribution of parasitic contamination on leafy vegetables (Tab. 
2) showed C. parvum \& Cyclospora spp. protozoa identified in $66(12 \%)$ and 54 $(10 \%)$ vegetable samples, respectively. Ascaris lumbricoides (123, 22\%) was the most frequently detected parasitic helminths, followed by Fasciola EMC (36, 7\%). Twenty parasitic species were identi-

\begin{tabular}{|l|c|c|c|c|}
\hline Parasites & Total & Eruca sativa & Raphanus sativus & Total frequency \% \\
\hline Entamoeba histolytica/dispar & 30 & 21 & 9 & 6.2 \\
\hline Endolimax nana & 3 & 3 & 0 & 0.62 \\
\hline Giardia lamblia & 36 & 24 & 12 & 7.4 \\
\hline Cryptosporidium parvum & 72 & 45 & 27 & 14.9 \\
\hline Cyclospora sp. & 54 & 36 & 18 & 11.1 \\
\hline Isospora sp. & 12 & 9 & 3 & 2.5 \\
\hline Eimeria sp. & 33 & 24 & 9 & 6.8 \\
\hline Blastocystis hominis & 21 & 18 & 3 & 4.3 \\
\hline Ascaris lumbercoides & 123 & 90 & 33 & 25.5 \\
\hline Trichocephalus trichiuris & 24 & 24 & 0 & 4.9 \\
\hline Toxocara canis & 15 & 9 & 6 & 3.1 \\
\hline Hymenolepis nana & 15 & 12 & 3 & 3.1 \\
\hline Fasciola EMC & 45 & 39 & 6 & 9.3 \\
\hline Total recovered parasites & 483 & 387 & 135 & 100 \\
\hline
\end{tabular}

Parasitic seasonal contamination showed that the highest rate was $(78 ; 87 \%)$ in winter and the lowest one $(66 ; 73 \%)$ was in autumn and none parasite was on $R$. sati$v u s$ in spring and summer (Tab. 3). Parasitic contamination rate on E. sativa was higher in spring $(87 \%)$ than in summer $(80 \%)$. According to frequency of parasites, there was significant seasonal variation for E. sativa $(P \leq 0.05)$ with the highest parasitic contamination in autumn, followed by spring, winter and then summer, respectively. But, $R$. sativus showed the highest parasitic contamination in winter than in autumn, without significant were the most prevalent and predominant fied (Figs. 1\&2). Of the 20 parasitic species, 14 were detected in $R$. sativus during this survey. But, Endolimax nana, coccidian cysts or oocytes, Trichocephalus trichiuris eggs, Toxocara canis eggs and metacercariae were only on E. sativa.

variation $(P \geq 0.05)$. Also, there was significant variation between $E$. sativa and $R$. sativa in autumn season $(P \leq 0.05)$, but not in winter (Tab. 4). The dendrogram of cluster analysis showed A. lumbricoides, C. parvum, Cyclospora sp., and Fasciola sp. EMC, the three major parasitic species in E. sativa and R. sativus. Each cluster contained species that were highly similar (Fig. 3). The dendrogram showed three different clusters: the first group in winter season was 67.5 , the second group in autumn season was 60 , and the third group was in spring and summer seasons were 22.5 .

Table 3: Prevalence of parasitic contamination in examined vegetables seasonally.

\begin{tabular}{|l|r|c|c|c|c|c|c|c|}
\hline \multirow{2}{*}{ Vegetables } & \multicolumn{2}{|c|}{ Autumn } & \multicolumn{2}{c|}{ Winter } & \multicolumn{2}{c|}{ Spring } & \multicolumn{2}{c|}{ Summer } \\
\cline { 2 - 8 } & No. & No.+ve & No. & No.+ve & No. & No. + ve & No. & No.+ve \\
\hline Eruca sativa & 45 & $39(86.7 \%)$ & 45 & $39(86.7 \%)$ & 45 & $39(86.7 \%)$ & 45 & $36(80 \%)$ \\
\hline Raphanus sativus & 45 & $27(60 \%)$ & 45 & $39(86.7 \%)$ & 0.0 & 0.0 & 0.0 & 0.0 \\
\hline Total & 90 & $66(73.3 \%)$ & 90 & $78(86.7 \%)$ & 45 & $39(86.7 \%)$ & 45 & $36(80 \%)$ \\
\hline
\end{tabular}
Table 4: Parasites recovered from plants on different seasons.

\begin{tabular}{|c|c|c|c|c|c|c|}
\hline & Autumn $(n=243)$ & Winter $(n=162)$ & Spring $(n=93)$ & Summer $(n=54)$ & \multirow{2}{*}{$X^{2}$} & \multirow[b]{2}{*}{$P$ value } \\
\hline Vegetables & No. (\%) & No. $(\%)$ & No. (\%) & No. (\%) & & \\
\hline E. sativa & $183(75.3 \%)$ & $90(55.6 \%)$ & $93(100 \%)$ & $54(100 \%)$ & 86.229 & $<0.001 * *$ \\
\hline R. sativus & $60(24.7 \%)$ & $72(44.4 \%)$ & $0(0.0)$ & $0(0.0)$ & 1.091 & 0.296 \\
\hline Total & 243 & 162 & 93 & 54 & & \\
\hline$x^{2}$ & 62.259 & 2.000 & - & - & & \\
\hline$P$ value & $<0.001 * *$ & 0.157 & - & - & & \\
\hline
\end{tabular}

Socio-demographic, health and handling prac-

tices of vendors were given (Tab. 5). There were 
significant $(P>0.05)$ differences between the contamination level on the vegetables based on sex, hand washing after use of toilet and washing hands during selling period over day. Mean and method of vegetables displayed positively increased contamination level $(P \leq 0.05)$, but vegetab-les put on the floor was more contaminated. There were no significant $(P \leq 0.05)$ differences between age, $\&$ education before

Table 5: Socio-demographic, hygiene and h

\begin{tabular}{|c|c|c|c|c|}
\hline Variable & Examined samples (270) & Positive samples (219) & $\mathrm{X}^{2}$ & $P$ value \\
\hline $\begin{array}{l}\text { Male } \\
\text { Female }\end{array}$ & $\begin{array}{l}135 \\
135\end{array}$ & $\begin{array}{l}130 \\
89\end{array}$ & 4.268 & $0.039 *$ \\
\hline $\begin{array}{c}\text { Age: } 20-30 \text { years } \\
30-40 \\
40-50 \\
\text { Above } 50 \\
\end{array}$ & $\begin{array}{l}118 \\
68 \\
68 \\
16 \\
\end{array}$ & $\begin{array}{l}90 \\
50 \\
63 \\
16\end{array}$ & 1.402 & 0.705 \\
\hline $\begin{array}{l}\text { Education } \\
\qquad \begin{array}{l}\text { No formal } \\
\text { Formal }\end{array}\end{array}$ & $\begin{array}{l}169 \\
101 \\
\end{array}$ & $\begin{array}{l}139 \\
80\end{array}$ & 0.040 & 0.842 \\
\hline $\begin{array}{c}\text { Washed before display } \\
\text { Yes } \\
\text { No } \\
\end{array}$ & $\begin{array}{l}101 \\
169 \\
\end{array}$ & $\begin{array}{l}89 \\
130 \\
\end{array}$ & 0.532 & 0.466 \\
\hline $\begin{array}{r}\text { Means of display } \\
\text { On floor } \\
\text { On table } \\
\end{array}$ & $\begin{array}{l}101 \\
169\end{array}$ & $\begin{array}{l}22 \\
97 \\
\end{array}$ & 16.325 & $<0.001 * *$ \\
\hline $\begin{array}{l}\text { Source of water } \\
\text { Tap water } \\
\text { Ground water }\end{array}$ & $\begin{array}{l}253 \\
17\end{array}$ & $\begin{array}{l}209 \\
10\end{array}$ & 0.694 & 0.405 \\
\hline
\end{tabular}

The present study showed that 219 out of 270 of vegetable samples were contaminated with different parasite species. This high level of parasitic contamination with overall prevalence $81 \%$ was in agreement with Ahmed et al. (2020) who reported that the overall prevalence of parasitic vegetable contamination was $84.1 \%$. On the other hand, several Egyptian studies showed different results from the present one. Said (2012) in Alexandria reported $31.7 \%$, Eraky et al, (2014) in Qualyobia Governorate reported (29.6\%) and Etewa et al. (2017) in Sharkia Governorate found $(39 \%)$ of vegetables were contaminated with different parasites.

The variations in the prevalence rates of parasitic contamination among different studies in Egypt may be attributed to the differences within the geographical location, climate, form of water used for irrigation, type and number of samples examined, methods used for the detection of the intestinal parasites, handling methods, and the display, source, and availability of water for washing, cleaning environment before and during selling) and contamination level. Majority of vendor's hygiene practices (washing vegetables claimed that they invited the sanitary officials for inspection positively affected contamination level $(P \leq 0.05)$. But, venders' knowledge about food poisoning and vegetable-borne diseases did not affect contamination level $(P>0.05)$

tices of vendors \& vegetables contamination

hygienic practices followed by the vendors. The current study showed high variations within the parasitic contamination between E. sativa (85\%) and $R$ sativus that showed lower rate of parasitic contamination $(73 \%)$. This difference in the rate could be related to differences in number of examined samples for each type as in our selected area $E$. sativa is available throughout the seasons, whereas $R$. sativus seeds are often plantonly in autumn and fall, but its growth is suspended during peak summer owing to high temperatures that may cause radishes to bolt thereby making them essentially useless (Stopforth et al, 2004). Therefore, no data on radish samples in summer and spring.

This finding agreed with that reported in Alexandria by Said (2012) and Sharkia by Etewa et al (2017). But, this finding disagreed with Hassan et al (2012) who found that the radishes showed the highest rate of parasitic contamination (50\%) in Alexandria. In this study, A. lumbricoides eggs 
were the most frequent parasites that contaminated the examined vegetables $(22 \%$ of Bkele et al. (2017) they showed that $A$. lumbericoides eggs were the most prominent parasites in raw vegetables. It was also detected in $20.3 \%$ of samples in Alexandria (Said, 2012). Al-Shawa and Mwafy (2007) reported that Ascaris eggs on vegetables indicated that human manure was used as fertilizers and food-handlers was infected and transmitted infection. Other helminth eggs such as Trichocephalus trichiuris, Toxocara canis, Hymenolepis nana and Fasciola EMC were detected in E. sativa samples. Presence of these parasites indicated the use of human manure as fertilizer, with possibility of vegetables contamination during handling. Etewa et al. (2017) in Sharkia found that Fasciola EMC were 1.4\% on the vegetables, especially on watercress samples (4.2\%).

Cryptosporidium parvum was the second frequently recovered parasitic contaminant $(12 \%)$, and the highest number was detected in E. sativa (64\%) than R. sativus (36\%).

The present rates were higher than other Egyptian studies as it was $29.3 \%$ in Alexandria (Said, 2012), and 7.6\% in Sharkia (Etewa et al, 2017). Abroad, in Ethiopia it was $7.6 \%$ (Alemu et al, 2019), in Norway, it was 4\% on lettuce (Robertson and Gjerde, 2001). The present study more or less agreed with Ahmed et al. (2020) in Assiut (69.4\%). Cryptosporidium oocysts strongly adhere to plants irrigated (Macarisin et al, 2010), canal water (Massoud et al, 2008), and C. parvum is notorious for its resistance to chlorine disinfection, a mainstay of water treatment, and zoonotic infections, arise from consuming contaminated food or water (Chalmers et al, 2019). Geological studies showed that the present study oasis had a water level significant drawdown (El Sabri and El Sheikh, 2009). Thus, the overuse of groundwater and reuse of irrigation water in agriculture increased the contamination of vegetables and fruits with coccidial infections. Other coccidian species such as Cyclospora oocysts represented $10 \%$ of all detected parasites. the entire number of the detected parasites). This agreed with Abougrain et al. (2010), \& The different higher and lower contamination rates were $21.3 \%$ in Alexandria (Said, 2012), and 1.4\% in Assiut (Ahmed et al. (2020). Abroad, it was $29.8 \%$ in Nepal (Sherchand et al, 2004), 1.8\% in Peru (Ortega et al. (1997).

In the present study, cysts of E. histolyti$c a$, and Blastocystis hominis were detected in $6 \%, \& 4.3 \%$, respectively. But, $B$ hominis varied among Egyptian authors between 10\% (Zuel-Fakkar et al, 2011), 7.1\% (Hassan et al, 2012), 6.8\% (Eraky et al, 2014); $6.2 \%$ (Etewa et al, 2017), and 4.1\% (Ahmed et al, 2020).

As to Isospora species, I. belli was found in one mentally retarded Egyptian patient in Cairo (Rifaat and Salem, 1963), and I. belli (9.7\%) among immunosuppressed children in Minia Governorate (Abdel-Hafeez et al, 2012). Eimeria is a genus of apicomplex parasites that includes various species capable of causing the disease coccidiosis in animals (Fayner, 1980). In Egypt, Eimeria species have high economic importance affected domestic rabbits El-Shahawi et al, 2012), sheep and goats (Mohamaden et al, 2018), camels (Abbas et al, 2019) and birds (Atef et al, 2020). Outbreaks of Egyptian and Saudi $C$. cayetanensis infection were due to consumption of food and water contaminated by oocysts that survived both physical and chemical disinfectants (Hussein et al, 2018).

In the present study, sex of the vender, means of display, type of water used for washing before display were significantly associated with the parasitic contamination of vegetables. This agreed with Tefera et al. (2014) in Ethiopia and Mohamed et al. (2016) in Sudan. In the present study, no significant association was between parasitic contamination, and washing vegetables before display $(P>0.05)$. Also, most vendors used tap water to wash the vegetables to reduce the rate of contamination, but this didn't totally eliminate parasitic and microbial contamination (Fallah et al, 2012). 


\section{Conclusion}

Generally, consumption of raw fruits and vegetables differentially predicted better health than the consumption of processed fruits and vegetables.

The high parasitic rate indicated the well washing of raw vegetables and fruits for human safety. Parasitosis need to be controlled at all stages of vegetables cultivation processing, manufacturing, shipping, and preparation in human consumptions mainly raw ones. People in affected areas should pay careful attention to hygiene.

\section{References}

Abbas, IE, El-Alfy, E, Al-Araby, M, Al-Kappany, Y, El-Seadawy, R, et al, 2019: Prevalence of Eimeria species in camels (Camelus dromedarius) from Egypt and variability in structure of Eimeria cameli oocysts. J. Parasitol. 105, 3:395400.

Abdel-Hafeez, EH, Ahmad, AK, Ali, BA, Moslam, FA, 2012: Opportunistic parasites among immunosuppressed children in Minia District, Egypt. Korean J. Parasitol. 1:57-62.

Abou el Naga, I, 1999: Studies on a newly emerging protozoal pathogen: Cyclospora cayetanensis. J. Egypt. Soc. Parasitol. 29:575-86.

Abougrain, A, Nahais, M, Madi, N, Said, M, Ghenghesh, K, 2010: Parasitological contamination in salad vegetables in Tripoli-Libya. Food Cont. 21:760-2.

Ahmed, AA, Sayed, FG, Galal, LG, Ismail, T, Gaber, MM, 2020: Detection of parasites contaminating raw consumable vegetables in Assiut City, Assiut Governorate, Egypt. J. Egypt. Soc. Parasitol. 50, 3:557-64

Ahmed, O, Abdel-Reheim, Ashour, M, Fahim, H, Mohamed, H, 2016: Efficacies of Eruca sativa and Raphanus sativus seeds' oils in streptozotocin induced diabetic rats. Int. J. Clin. Endocrinol. Metab. 2:34-43.

Al-Agroudi, MA, Morsy, ATA, Ismail, MAM M, Morsy, TA, 2016: Protozoa causing food poisoning. J. Egypt. Soc. Parasitol. 46, 2:497508

Alemu, G, Mama, M, Misker, D, Haftu, D, 2019: Parasitic contamination of vegetables marketed in Arba Minch town, southern Ethiopia. BMC Infect. Dis.19:410-6.

Al-Megrin, WA, 2010: Prevalence of intestinal parasites in leafy vegetables in Riyadh, Saudi Arabia. Int. J. Trop. Med. 5, 2:20-3

Al-Shawa, R, Mwafy, S, 2007: The enteropara- sitic contamination of commercial vegetables in Gaza Governorate. J. Infect. Develop. Countr. 1. 62-6.

Atef, M, El-Banna, HA, Elzorba, HY, Soliman, AM, 2020: Pharmacokinetics and tissue residue of enrofloxacin in healthy, Eimeria-infected broiler chickens and those pre-treated with amprolium and toltrazuril. Int. J Vet. Sci. Med. 8, 1: 31-8.

Bekele, F, Tefera, T, Biresaw, G, Yohannes, T, 2017: Parasitic contamination of raw vegetables and fruits collected from selected local markets in Arba Minch Town, Southern Ethiopia. Infect. Dis. Poverty 7, 6:1-19.

Chalmers, RM, Davies, AP, Tyler, KA, 2019: Cryptosporidium. Microbiology (Reading) 165, 5:500-2

Daryani, A, Ettehad, GH, Sharif, M, Ghorbani, L, Ziaei, H, 2008: Prevalence of intestinal parasites in vegetables consumed in Ardabil, Iran. Food Cont. 19:790-4.

El Bakri, A, Hussein, NM, Ibrahim, ZA, Hasan, H, AbuOdeh, R, 2020: Intestinal parasite detection in assorted vegetables in the United Arab Emirates. Oman Med. J. 35, 3:e128.doi: 10.5001/omj.2020.46

El Sabri, M, El Sheikh, A, 2009: Groundwater sustainability of the post Nubian sandstone aquifer in Farafra Oasis, Western Desert, Egypt. J. Sci. 3:64-72.

El-Bahnasawy, MM, Mohammad, AE, Morsy, TA, 2014: Hydrocarbon insecticides: Their risks for environment and human health. J. Egypt. Soc. Parasitol. 44, 2:361-72

El-Khabaz, KA, Abdel-Hakeem, SS, Arfa, M I, 2019: Protozoan and helminthes parasites endorsed by imported camels (Camel dromedaries) to Egypt. J. Parasit. Dis. 43:60715.

El-Naggar, SM, El-Bahy, MM, Abd Elaziz, J, EI-Dardiry, MA, 2006: Detection of protozoal parasites in the stools of diarrhoeic patients using different techniques. J. Egypt. Soc. Parasitol. 36, 1:7-22.

El-Shahawi, GA, El-Fayomi, HM, Abdel-Haleem, HM, 2012: Coccidiosis of domestic rabbit (Oryctolagus cuniculus) in Egypt: Light microscopic study. Parasitol. Res. 110, 1:251-8

Elmi, M, 2008: Food safety. East. Mediterr. Hlth. J. 14:S143-9.

Eraky, MA, Rashed, SM, Nasr, ME, El-Hamshary, AMS, El-Ghannam, AS, 2014: Parasitic contamination of commonly consumed fresh leafy vegetables in Benha, Egypt. J. Parasit. Res. 
7 doi.org/10.1155/2014/613960

Etewa, SE, Abdel-Rahman, SA, Fathy, GM, Abo El-Maaty, DA, Sarhan, MH, 2017: Parasitic contamination of commonly consumed fresh vegetables and fruits in some rural areas of Sharkia Governorate, Egypt. J. Infect. End. Dis 7: 192-202.

Fallah, A, Pirali-Kheirabadi, K, Shirvani, F, Saei-Dehkordi, S, 2012: Prevalence of parasitic contamination in vegetables used for raw consumption in Shahrekord, Iran: Influence of season and washing procedure. Food Cont. 25:617-20.

Fayner, R, 1980: Epidemiology of protozoan infections: Coccidia. Vet. Parasitol. 6:75-103.

Hassan, A, Farouk, H, Abdul-Ghani, R, 2012: Parasitological contamination of freshly eaten vegetables collected from local markets in Alexandria, Egypt: A preliminary study. Food Cont. 26, 2:500-3

Hassan, A, Farouk, H, Abdul-Ghani, R, 2012: Parasitological contamination of freshly eaten vegetables collected from local markets in Alexandria, Egypt: A preliminary study. Food Cont. 26:500-3.

Herman, KM, Hall, AJ, Could, LH, 20015: Outbreaks attributed to fresh leafy vegetables, United States, 1973-2012. Epidemiol. Infect. 143, 14:3011-21.

Hussein, EM, Ahmed, SA, Mokhtar, A, Elzagawy, SM, Yahi, SH, et al, 2018: Antiprotozoal activity of magnesium oxide (MgO) nanoparticles against Cyclospora cayetanensis oocysts. Parasitol, Int. 67, 6:666-74.

Iwu, CD, Okoh, AI, 2019: Preharvest transmission routes of fresh produce associated bacterial pathogens with outbreak potentials: A review. Inter. J. Environ. Res. Publ. Hlth. 16:4407-14. Li, J, Wang, Z, Karim, MR, Zhang, L, 2020: Detection of human intestinal protozoan parasites in vegetables and fruits: a review. Parasit. Vectors 13, 1:380.

Macarisin, D, Bauchan, G, Fayer, R, 2010: Spinacia oleracea, L. leaf stomata harboring $\mathrm{Cr}$ yptosporidium parvum oocysts: A potential threat to food safety. Appl. Environ. Microbiol. 76: 555-9.

Mahmoud, GAE, Osman, YA, Abdel-Hakeem, SS, 2020: Hydrolytic bacteria associated with natural helminth infection in the midgut of Red Sea marbled spine foot rabbit fish Siganus rivulatus. Microbial. Pathol. 147:104404.

Massoud, AMA, Hafez, AO, Abdel-Gawad, E A, El Shazly, AM, Morsy, TA, 2008: Mirazid alone or combined with paromomycin in treating cryptosporidiosis parvum in immunocompetent hospitalized patients. J. Egypt. Soc. Parasitol. 38, 2:399-418.

Mohamaden, WI, Sallam, NH, Abouelhassan, M, 2018: Prevalence of Eimeria species among sheep and goats in Suez Governorate, Egypt. Int. J. Vet. Sci. Med. 6, 1:65-72.

Mohamed, M, Siddig, E, Elaagip, A, Edris, A, Nasr, A, 2016: Parasitic contamination of fresh vegetables sold at central markets in Khartoum State, Sudan. Ann. Clin. Microbiol. Antimicrob. 15:17-9.

Okyay, P, Ertug, S, Gultekin, B, Omen, O, Beser, E, 2004: Intestinal parasites prevalence and related factors in school children, a western city sample - Turkey. BMC Publ. Hlth. 4:64-8.

Ortega, YR, Roxas, CR, Gilman, RH, Miller, NJ, Cabrera, L, et al, 1997: Isolation of Cryptosporidium parvum and Cyclospora cayetanensis from vegetables collected in markets of an endemic region in Peru. Am. J. Trop. Med. Hyg. 57:683-6.

Rifaat, MA, Salem, SA, 1963: A case of human infection with Isospora belli in Egypt. Trans. R. Soc. Trop. Med. Hyg. 57:213

Robertson, LJ, Gjerde, B, 2001: Occurrence of parasites on fruits and vegetables in Norway. $\mathrm{J}$. Food Protect. 64, 11:1793-8.

Said, DE, 2012: Detection of parasites in the commonly consumed the raw vegetables. Alex. J. Med. 48:345-52.

Sherchand, JB, Cross, J, Jimba, M, Sherchand, S, Shrestha, M, 2004: Study of Cyclospora cayetanensis in health care facilities, sewage water and green leafy vegetables in Nepal. Southeast Asian J. Trop. Med. Publ. Hlth. 30:58-63.

Slavin, JL, Lloyd, B, 2012: Health benefits of fruits and vegetables. Adv. Nutr. 3, 4:506-16.

Slifko, T, Smith, H, Rose, J, 2000: Emerging parasite zoonoses associated with water and food. Inter. J. Parasitol. 30:1379-93.

Stopforth, JD, Ikeda, JS, Kendall, PA, Stofos, JN, 2004: Survival of acid- adapted or non-adapted Escherichia coli O157:H7 in apple wounds and surrounding tissue following chemical treatments and storage. Inter. J. Food Microbiol. 90: 51-61.

Takayanagui, OM, Capuano, DM, Oliveira, CAD, Bergamini, AMM, Okino, MHT, et al, 2007: Evaluation of the contamination of lettuce crops after the establishment of the monitoring system in Ribeirão Preto sp. J. Braz. Soc. 
Trop. Med. 40:239-41.

Tefera, T, Biruksew, Mekonnen, Z, Eshetu, T, 2014: Parasitic contamination of fruits and vegetables collected from selected local markets of Jimma Town, Southwest Ethiopia. Int. Schol. Res. Not. doi:10.1155/2014/382715.

WHO, 2002: Global surveillance of foodborne disease: Developing a Strategy and its Interaction with Risk Analysis. Geneva, Switzerland.

WHO, 2003: Diet, Nutrition, and the Prevention of Chronic Diseases: Report of joint WHO/ FAO Expert Consultation, Geneva, Switzerland.

Yeni, F, Yavaş, S, Alpas, H, Soyer, Y, 2016: Most common foodborne pathogens and mycotoxins on fresh produce: A review of recent outbreaks. Crit. Rev. Food Sci. Nutr. 56:1532-44.

Zuel-Fakkar, NM, Abdel Hameed, DM, Hassanin, OM, 2011: Study of Blastocystis hominis isolates in urticaria: A case-control study. Clin. Exp. Dermatol. 36, 8:908-10.

\section{Explanation of figures}

Fig. 1: a- cysts of E. histolytica, b- Endolimax nana, c- Giardia lamblia, d- Cryptosporidium parvum oocysts stained with Zielh Nelsen stain, e- Isospora belli, f-. Eimeria spp.sporulated oocyst, g- Eimeria unsporulated oocyst, h- Blastocystis hominis, and i- Cyclospora cayetanensis.

Fig. 2: a- Ascaris lumbricoides egg, b- Toxocara canis egg, and c- Hymenolepis nana egg.

Fig. 3: Dendogram showed clusters of parasites seasonal abundance.

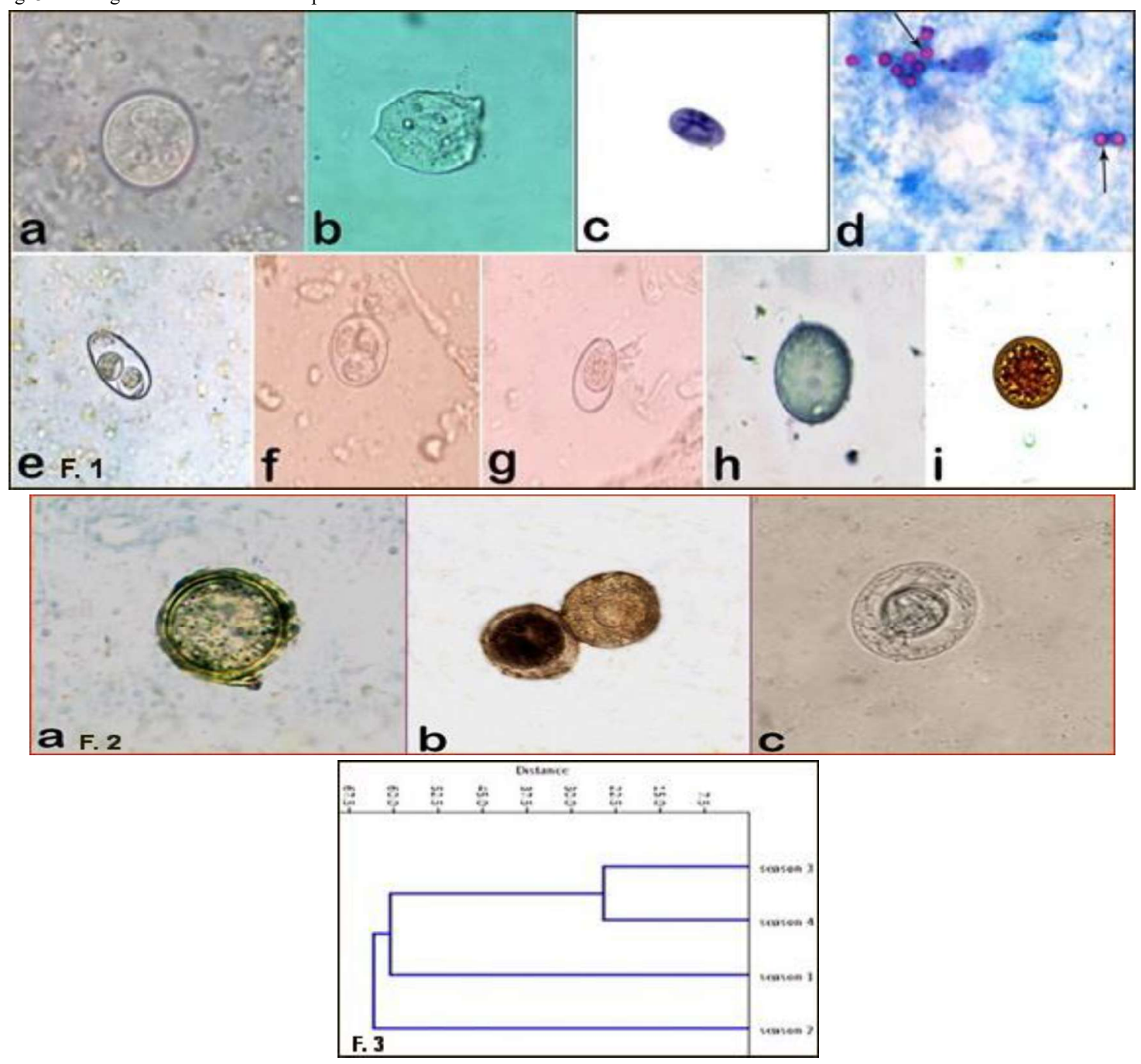

